\title{
THE ROLE OF THE POLICE IN DISASTERS CAUSED BY PANDEMIC INFECTIOUS DISEASES
}

\author{
Bojan Janković ${ }^{1}$ \\ ${ }^{1}$ University of Criminal Investigation and Police Studies, 196 Cara Dušana Street, 11080 \\ Belgrade-Zemun, The Republic of Serbia \\ Correspondence: bojan.jankovic@kpu.edu.rs
}

\begin{abstract}
So far, the police have played and are playing a very important role in the fight against pandemics in the current situation. Recent events have indicated the need to pay as much attention to the role of the police in emergencies caused by pandemics (epidemics) of infectious diseases, because it is noticeable that, in the previous period, either in practice or in scientific circles, not enough attention was paid to this segment of police work. The author's wish was to provide an answer to the question whether and in what way the police coped with the natural disaster caused by the pandemic of the infectious disease COVID-19. The answer would be that the police did not cope during the COVID-19 pandemic. The paper provides guidelines that would help police organizations cope with possible future natural disasters caused by a pandemic of infectious diseases in a better way.
\end{abstract}

Keywords: police, disaster, pandemic, COVID-19

\section{Introduction}

Police operations represent a line of police actions and activities that encompass activities done by different organizational parts of the police towards achieving the set goal on the territory of a certain state or its part, all in cooperation with the police from different countries (Milojević \& Janković, 2014). Police operations are various, depending on the state of security in which these operations are undertaken. In relation to the state of security, police operations are divided into peace operations, wartime operations, operations in the state of emergency and emergency situation operations (Milojević \& Janković, 2014).

While it is obvious which operations are carried out in war or in peace, it is often unclear to the public what is meant by a state of emergency and the emergency situation. Summarized, the distinction between a state of emergency and the emergency situation could be defined based on the degree of danger and the severity of the threat. In an emergency situation, the danger and threat are less severe than in a state of emergency. The danger that leads to a state of emergency is so great and serious that it endangers the very survival of the state. Some authors therefore state that a state of emergency can be declared "in the case of largescale civil riots in which violence threatens the survival of the state or its citizens" (Lončar, 
Radivojević, Radošević, \& Mirković, 2019). The state of emergency, therefore, endangers the constitutional order itself and is a constitutional category, while the legal treatment of emergency situations in the Republic of Serbia is regulated by the Law on Disaster Risk Reduction and Emergency Management (The Law on Disaster Risk Reduction and Emergency Management, 2018). Here the emergency situation is defined as "a situation arising from a declaration by the competent authority when risks and threats or consequences for the population, environment and material and cultural goods are of such scope and intensity that their occurrence or consequences cannot be prevented or eliminated by regular actions of bodies and services, which is why it is necessary to use special measures, forces and means with an intensified regime of work for their mitigation and elimination". The danger that requires the declaration of an emergency situation arises from natural disasters, technical and technological accidents, pandemics of infectious diseases, in a word, according to the legal terminology - from disasters (Lončar et al., 2019). The difference drawn in this way is not entirely precise, reliable and strict, since the circumstances that lead to emergency situations can also lead to a state of emergency. In other words, due to the appropriate danger, emergency situations can grow into a state of emergency. Such an example was in Serbia in 2020, during the COVID-19 pandemic, when the level of risk of coronavirus was estimated to be extremely high. On March 16, the state leadership decided to declare a state of emergency, which allowed the use of a wider range and intensity of emergency measures in an emergency situation due to the pandemic (Cvetković et al., 2020) and enabled wider police engagement.

Previous experiences have shown that the police are poorly prepared for challenges related to large-scale disasters, such as floods, earthquakes and the like (Cvetković, 2014, 2016; Goyal, 2019; Janković \& Cvetković, 2020; Sheptycki, 2020; Varano \& Schafer, 2012). Also, in the previous period it has been pointed out that, in the field of emergency planning, the police and other segments of the community are insufficiently trained, without experience and technological infrastructure to be able to respond to disasters effectively (Brito, Luna, \& Sanberg, 2009; Luna, Brito, \& Sanberg, 2007; Varano \& Schafer, 2012). A review of the scientific literature examining the place and role of the police in natural disasters reveals four categories of issues raised in this context, relations between the police and the community, mental health of police officers in disasters, organizational challenges within police organizations and inter-agency cooperation (Laufs \& Waseem, 2020).

The COVID-19 pandemic is the "first global police event" that represented the cause for researchers and scientists to apply existing theories and empirical research in emergencies (Sheptycki, 2020). With this paper, the author wants to join this group of researchers in order to answer whether and in what way the police coped with the natural disaster caused by the pandemic of the COVID-19 infectious disease. In addition, the author wants to present general guidelines that police organizations should adhere to in all pandemics in order to cope with such specific situations successfully.

\section{Police operations during the pandemic of the COVID-19 infectious disease}

The first broader police engagement to combat infectious diseases was during the Spanish flu pandemic, from 1918 to 1920, as it was the deadliest disease in human history. It is estimated that 50 million people died from the disease worldwide. One of the tasks of the Chicago police was to arrest any citizen who coughed or sneezed in public (Luna et al., 2007). On the other hand, the police also faced internal challenges; therefore, 500 police officers in Philadelphia did not come to work for fear of becoming infected (Luna et al., 2007). 
There have been many epidemics of various infectious diseases in the history of the Republic of Serbia starting from the plague and cholera epidemics in the Middle Ages, to the outbreak of smallpox, swine flu and the COVID 19 pandemic. In 1972 in the Republic of Serbia, during the smallpox (Variola Vera) epidemics, the police were broadly engaged in securing quarantine (Kekić \& Milenković, 2020). There were as many as eight quarantines in Belgrade in which patients were accommodated, four of which were in hospitals, while four were housed in adapted civilian facilities - hotels and motels (Kekić \& Milenković, 2020).

The last pandemic of the viral disease COVID 2019, which started in China, did not bypass the Republic of Serbia. The first case was registered in Serbia on March 6, 2020, and like most of the following, it occurred when infected citizens of Serbia returned to their homeland in large numbers from countries that had already been affected by the pandemic. Global pandemic panic has resulted in a dramatic increase in border control (Sheptycki, 2020). Due to the large influx of Serbian citizens at the border crossings, nearly 400,000 during the first month, there was no time for classic checks (Djordjevic, 2020). Each member of the border police did passenger profiling individually, ad hoc, based on the previous experience, interviews and vehicle and luggage checks (Janković \& Cvetković, 2020). The citizens of Serbia who came from the countries affected by the pandemic, were imposed a measure of self-isolation for 28 days, based on the decision of the sanitary inspector, delivered at the border crossing (Cvetković et al., 2020). After arriving in Serbia, police officers checked their quarantine by phone several times a day in the beginning, which was a huge job, because at certain times there were between 70,000 and 100,000 citizens in self-isolation (Janković \& Cvetković, 2020). If the citizen did not answer the phone calls, the police patrols, upon arriving at the home address, determined whether the particular person was at the residential address. Checks were performed in such a way that they were carried out at different time intervals, so that persons would not know the exact time of the control (Đorđević, 2020). The third method of control, especially of Serbian citizens who came from abroad, was to monitor their movements based on foreign mobile phone numbers (not wiretapping). If the citizens were not found, a search was announced for them, and after they were found, criminal charges were filed against them for the criminal offense "Failure to comply with health regulations during the epidemic" (Turanjanin \& Radulović, 2020).

Apart from citizens who came from abroad, citizens with a residence in Serbia were also controlled, because in one period they were also subject to restrictions and prohibitions on the movement of persons, the control of which members of the police were in charge (Djordjevic, 2020). The first type of permanent restriction of movement referred to elderly citizens over 65 years of age. The second restriction of movement was valid for all citizens, regardless of age, every day from 5:00 PM, until the next morning until 5:00 AM. According to the MOI of the Republic of Serbia, $4 \%$ to $5 \%$ of Serbian citizens violated the ban on movement during curfew, or 25 every 100,000 citizens did not respect the measure of restricting the movement of citizens (Janković \& Cvetković, 2020).

In the Republic of Serbia, while at work during the first month of the pandemic, 17 police officers were diagnosed with COVID-19, and about 800 of them were in self-isolation due to virus symptoms or suspicious contacts with infected people, which was $2.34 \%$ of all police officers (Janković \& Cvetković, 2020). As there was a danger of the disease spreading among police officers, $10 \%$ of them were sent on forced annual leave. This was done in order to save a number of police officers as a reserve in case of a possible larger number of infected police officers. In Detroit, 1,000 were quarantined out of about 2,800 employees (Hansen \& Lory, 2020). In New York, in the first month of the COVID-19 pandemic, 1,500 police officers (about 4\%) were infected, and one in six police officers was quarantined (Ashby, 2020). 


\section{Guidelines for police procedures during pandemics (epidemics) of infectious diseases}

Similar to critical incidents caused by a man or natural events such as floods or earthquakes, viral pandemics (epidemics) also affect the police work (Jennings \& Perez, 2020). Most critical incidents occur only in a limited geographical area and do not last very long, allowing other unaffected emergency services to assist the community in the most severe incidents (Brito et al., 2009). The pandemic, on the other hand, affects several regions at the same time and can continue over a longer period of time, creating challenges locally, nationally, and even globally (Jennings \& Perez, 2020).

In every legal system, in the conditions of pandemics (epidemics), the authorities face situations in which they have to make choices, but are in doubt what measures to take, and all that affects the work of the police (Kekić \& Milenković, 2020). During pandemics, priority tasks can be divided into five main categories: implementation of quarantine or the complete lockdown; finding alternatives to arresting and detaining criminal suspects; support and assistance to health professionals; dealing with new forms of crime, such as the sale of counterfeit medical and protective equipment; and providing police information on social networks and their monitoring in order to provide timely information and prevent the occurrence of various forms of social unrest (Kekić \& Milenković, 2020).

Within these categories of tasks, among the priority ones in the initial stages are the implementation of quarantine or complete blockade and assistance to health workers. Within these categories, specific tasks are performed, such as enforcing public health orders to quarantine or restrict travel, securing the perimeter of infected areas, securing health facilities, mass control (crowding), investigating cases of infection, protecting national stocks of vaccines and drugs, etc. Because of the increased engagement in certain tasks, it is sometimes necessary for certain police officers and other police employees to be transferred to perform other tasks. This also happened in the Serbian police, during the COVID-19 pandemic, where employees in the administrative affairs did telephone checks to see if particular citizens were in their apartments during the quarantine (Janković \& Cvetković, 2020). A similar procedure was followed in New York, where about 700 police officers were redirected from other duties so that the police could respond to calls from citizens because of violation of social distancing regulations (Ashby, 2020).

Police officers have also performed other tasks in order to counter the pandemic of the virus, primarily seeking the contacts of infected persons in order to shelter such persons in self-isolation. Special telephone numbers and e-mail addresses have been opened for obtaining information; the suppression of the illegal sale of medical equipment and consumer goods has been intensified; the police are regulating the queues in front of shops, banning gatherings of several people, etc. (Janković \& Cvetković, 2020).

Police tasks change significantly during the pandemic compared to the daily ones that are carried out before it. Police actions must adapt to the new situation, because there is a change in crime rates (Hansen \& Lory, 2020; Stickle \& Felson, 2020), types of crimes (Hansen \& Lory, 2020; Stickle \& Felson, 2020), phone calls from citizens (Ashby, 2020; Hansen \& Lory, 2020), etc. During the pandemic, citizens call on the police not only to deal with serious crimes or serious threats to public safety, but also because of a wide range of tasks for maintaining public order, from disputes between neighbors, minor traffic accidents, to providing non-police information (Sukhwani, Gyamfi, Zhang, AlHinai, \& Shaw, 2019). In the United States, the total number of calls to the police decreased during the pandemic (Ashby, 2020). However, the range of crime-related calls during the first three weeks of the quarantine was different, as calls related to physical attacks decreased while calls for burglaries increased (Ashby, 2020). 
In New York, for example, in the first month of the pandemic, there was an increase in telephone calls to the police due to domestic violence, so in March 2020 there were 1753 phone calls compared to1522 phone calls in March 2019 (Hansen \& Lory, 2020). There has been a decrease in the number of calls related to traffic accidents since the announcement of quarantine measures (Ashby, 2020). However, in the later weeks of quarantine, there was an increase in the number of calls related to traffic accidents, which can be explained by the "quarantine fatigue", i.e. citizens became nervous after being closed in their homes for several weeks (Ashby, 2020). The research in Sweden (Stickle \& Felson, 2020) indicated that during the first five weeks after government restrictions began, there was an $8.8 \%$ drop in the reported crime. Specifically, in the case of burglaries, that decrease was $23 \%$; in the case of car theft, it was as much as $61 \%$. However, there was an increase in the number of drug-related crimes. All of the above indicates that police organizations should be flexible in planning the response to changes in the frequency of calls and changes in the rates of certain types of crime. A detailed understanding of changes in calls to the police will make it possible for police leaders to establish evidence-based plans to ensure adequate responses in the future. Thus, each police organization should analyze the calls made to it during the COVID-19 pandemic in order to make adequate plans for future pandemics of various diseases.

Since the police are at the forefront in the fight against the pandemic and implementation of measures to respond to it, they are at a higher risk of exposure to the infection at the same time. Therefore, it is very important to protect police officers from possible infection, without diminishing the effect of police activity. Consequently, personal protective equipment has become essential for police officers to reduce these health risks. Police officers who are in direct contact with citizens are required to wear protective equipment, such as disposable gloves, disposable coats or overalls, protective masks (markings $\mathrm{N} 95^{1}$ or higher), eye protection such as goggles or visors for single use (Luna et al., 2007). It is recommended that if a police officer comes into contact with a person during an arrest, uses coercive means, or takes any other official action, his or her equipment should be cleaned and disinfected before reuse (Jennings \& Perez, 2020). In addition to protective equipment, it is necessary to vaccinate the entire staff employed in the police organization in accordance with the recommendations of public health institutions.

In addition to the danger of infection caused by a close contact, the problem of intentional contamination of police officers has also been highlighted in recent times. In March 2020, the FBI warned local police agencies that extremist groups, such as neo-nationalists and similar organizations, encouraged their members to deliberately spread the virus to police officers by spraying body fluids on police officers on the streets (Jennings \& Perez, 2020). At the same time, police officers also reported incidents of intentional spitting and coughing by people who claimed to have been positive for the virus (Jennings \& Perez, 2020).

Police officers cannot carry out all preventive measures, i.e. they cannot perform their duties without direct personal contact with citizens. However, the volume of individual non-priority jobs may be reduced. Therefore, the basic functions of the police unit carried out in emergencies should be recognized. They can be classified into three categories: those that must be continued during an emergency, those that can be suspended but should be resumed as soon as possible after the incident, and those that may be suspended until the return to normal conditions (Luna et al., 2007). For example, one of those that can be suspended until the return to normal conditions is the termination of counter services, their transition to work online from home, as well as other administrative tasks and all meetings in the police, both internal and external with the local community (Janković \& Cvetković, 2020).

1 Multilayered mask (4 protective layers) offering 95\% of protection from toxic particles 2 to 5 micrometer big. Certified as FFP2 or N 95 protective mask. 
To reduce the likelihood of exposure of all police officers to the virus at once, some police organizations made a 50/50 plan, dividing employees in half and keeping the two groups completely separate from each other (Jennings \& Perez, 2020). One of the possible measures is the suspension of all ceremonies, trainings and all activities that are not necessary at a given moment (Janković \& Cvetković, 2020). The police station premises should be ventilated and disinfected more often, and a smaller number of citizens wearing protective masks should be allowed to enter them. (Luna et al., 2007).

A prerequisite for successful counteracting an infectious disease pandemic is adequate police planning (Cvetković \& Janković, 2020). The threat of a pandemic of infectious diseases is not new, but it has recently been recognized as a real danger for which police organizations must be prepared. Many police organizations around the world, including the police in the Republic of Serbia, have created emergency response plans in case of the loss of infrastructure, communications and information technology (Hansen \& Lory, 2020; Janković \& Cvetković, 2020). However, many of them have yet to consider the loss of human resources and the effects of such a loss on police units and the community during a pandemic (Luna et al., 2007). The need for planning is critical because a pandemic can spread through a population in days and weeks, and in contrast, it can take months to develop pandemic plans.

The police must be involved in external planning, and must make their own plans (internal planning) to respond to a pandemic (Luna et al., 2007). Police organizations must provide an integrated response to a pandemic through partnerships with other emergency services (Al-ramlawi, El-Mougher, \& Al-Agha, 2020; Hansen \& Lory, 2020; Jennings \& Perez, 2020; Varano \& Schafer, 2012). While public health institutions have already formulated plans for a pandemic, the description of the role of the police in these plans is often generalized by statements that the police will "assist and support other state bodies and local services wherever possible" (Luna et al., 2007).

When emergency public health operational plans are activated, the police should activate their internal plans. The moment of activation of the plan may be different. It may be when the World Health Organization declares a pandemic of a certain infectious disease or when the Ministry of Health declares an epidemic of a contagious disease on the territory of the Republic of Serbia (Brito et al., 2009).

When planning, it must be taken into account that due to the pandemic and the infection of police officers, there may be a reduction in the workforce. Plans are prepared for the possibility that from $10 \%$ to as many as $80 \%$ of police unit employees may be lost or unable to work (Luna et al., 2007). On the other hand, contrary to the absence of employees, those who remain at work may become seriously tired trying to compensate for the loss of other staff, and this should be taken into account when planning.

\section{Conclusion}

During the pandemics, police officers played a significant role in providing public services and maintaining order. So far, the police have played, and are playing a very important role in the fight against the pandemic. Recent events have indicated the need to pay as much attention to the role of the police in emergencies caused by pandemics (epidemics) of infectious diseases, because it is noticeable that in the previous period, either in practice or in scientific circles, not enough attention was paid to the fact how much the police were able to help the society in overcoming one of the most difficult periods in human history. 
One of the main lessons that police organizations have learned in recent years is that mistakes that occur during work cannot be hidden. However, to reduce their number, it is necessary to undertake adequate planning in order to minimize the probability that police officers would make a mistake. However, police organizations must move away from the traditional police mentality to define every possible incident and event clearly and in detail, because the very nature of emergencies often defies clear prediction and articulation. Therefore, police officers need to be given a clear operational framework, but even then, they need discretion and flexibility to make plans and approaches based on situational needs in relation to the given circumstances. Even within a particular category of emergencies, there are elements that differ, so that two different pandemics may require very different police responses. Therefore, it is necessary for police managers to complete special training, which would relate to police planning in specific situations, because it turned out that police organizations in the previous period did not have plans how to act in such situations. In addition to managers, each police officer should complete additional training aimed at responding to emergencies caused by pandemics of infectious diseases, because it is obvious that in the previous period they were not adequately prepared to react in the right way. Such training should be included in programs of educational institutions in charge of police education.

\section{References}

1. Al-ramlawi, A. H., El-Mougher, M. M., \& Al-Agha, M. R. (2020). The Role of Al-Shifa Medical Complex Administration in Evacuation \& Sheltering Planning. International Journal of Disaster Risk Management, 2(2), 19-36. doi:10.18485/ijdrm.2020.2.2.2

2. Ashby, M. P. J. (2020). Changes in Police Calls for Service During the Early Months of the 2020 Coronavirus Pandemic. Policing: A Journal of Policy and Practice. doi:10.1093/police/ paaa037

3. Brito, C. S., Luna, A. M., \& Sanberg, E. L. (2009). Benchmarks for developing a law enforcement pandemic flu plan. Washington, D.C: Police Executive Research Forum.

4. Cvetković, V. M., \& Janković, B. (2020). Private security preparedness for disasters caused by natural and anthropogenic hazards. International Journal of Disaster Risk Management, 2(1), 23-33.

5. Cvetković, V. M. (2014). Uloga policije u prirodnim katastrofama [The role of police in natural disasters]. In Elementarne nepogode i vanredne situacije (pp. 217-225). Belgrade: The Academy of Criminalistic and Police Studies.

6. Cvetković, V. M. (2016). Policija i prirodne katastrofe [Police and natural disasters]. Beograd: Zadužbina Andrejević.

7. Cvetković, V. M., Nikolić, N., Nenadić, U. R., Öcal, A., Noji, E. K., \& Zečević, M. (2020). Preparedness and Preventive Behaviors for a Pandemic Disaster Caused by COVID-19 in Serbia. Int J Environ Res Public Health, 17(11). doi:10.3390/ijerph17114124

8. Đorđević, S. (2020). Policija u vreme vanrednog stanja [Police during a state of emergency]. Beograd: Beogradski centar za bezbednosnu politiku

9. Goyal, N. (2019). Disaster Governance and Community Resilience: The Law and the Role of SDMAs. International Journal of Disaster Risk Management, 1(2), 61-75. doi:10.18485/ ijdrm.2019.1.2.5

10. Hansen, J. A., \& Lory, G. L. (2020). Rural Victimization and Policing during the COVID-19 Pandemic. American Journal of Criminal Justice, 45(4), 731-742. doi:10.1007/ s12103-020-09554-0 
11. Janković, B., \& Cvetković, V. M. (2020). Public perception of police behaviors in the disaster COVID-19 - the Case of Serbia. Policing: An International Journal, 43(6), 979-992. doi:10.1108/PIJPSM-05-2020-0072

12. Jennings, W. G., \& Perez, N. M. (2020). The Immediate Impact of COVID-19 on Law Enforcement in the United States. American Journal of Criminal Justice, 45(4), 690-701. doi:10.1007/s12103-020-09536-2

13. Kekić, D. \& Milenković, M. (2020). Role of the Serbin police in maintaining security in the conditions of the epidemic of infectious diseases. In S. Jaćimovski (Ed.), Archibald Reiss Days, 2020 (pp. 281-290): University of Criminal Investigation and Police Studies.

14. Laufs, J., \& Waseem, Z. (2020). Policing in pandemics: A systematic review and best practices for police response to COVID-19. Int J Disaster Risk Reduct, 51, 101812. doi:10.1016/j. ijdrr.2020.101812

15. Lončar, Z. J., Radivojević, N. P., Radošević, R. S., \& Mirković, V. M. (2019). Saradnja policije i privatnog obezbeđenja u vanrednim situacijama u Republici Srbiji - stanje i mogućnosti - [Cooperation between Police and Private Security in Emergency Situations in the Republic of Serbia - Current State and Possibilities]. Zbornik radova Pravnog fakulteta, Novi Sad, 53(1), 113-131. doi:10.5937/zrpfns53-22005

16. Luna, A. M., Brito, C. S., \& Sanberg, E. A. (2007). Police Planning for an Influenza Pandemic: Case Studies and Recommendations from the Field. Washington, DC: Police Executive Research Forum.

17. Milojević, S., \& Janković, B. (2014). Osnovi taktike policijskih jedinica posebne namene [Basics of the tactics of special-purpose police units]. Beograd: Kriminalističko-policijska akademija.

18. Sheptycki, J. (2020). The politics of policing a pandemic panic. Australian \& New Zealand Journal of Criminology, 53(2), 157-173. doi:10.1177/0004865820925861

19. Stickle, B., \& Felson, M. (2020). Crime Rates in a Pandemic: the Largest Criminological Experiment in History. American Journal of Criminal Justice, 45(4), 525-536. doi:10.1007/ s12103-020-09546-0

20. Sukhwani, V., Gyamfi, B. A., Zhang, R., AlHinai, A. M., \& Shaw, R. (2019). Understanding the Barriers Restraining Effective Operation of Flood Early Warning Systems. International Journal of Disaster Risk Management, 1(2), 1-17. doi:10.18485/ijdrm.2019.1.2.1

21. Turanjanin, V., \& Radulović, D. (2020). Coronavirus (COVID-19) and Possibilities for Criminal Law Reaction in Europe: A Review. Iran J Public Health, 49(1), 4-11.

22. Varano, S. P., \& Schafer, J. A. (2012). Policing Disasters: The Role of Police in the Pre-Disaster Planning and Post-Disaster Responses. In M. Deflem (Ed.), Disasters, Hazards and Law (Sociology of Crime, Law and Deviance) (Vol. 17, pp. 83-112). Bingley: Emerald Group Publishing Limited.

23. Zakon o smanjenju rizika od katastrofa i upravljanju vanrednim situacijama [The Law on Disaster Risk Reduction and Emergency Management], (2018). 